Review

\title{
Applications of Biosurfactants in the Petroleum Industry and the Remediation of Oil Spills
}

Rita de Cássia F. S. Silva ${ }^{1,2}$, Darne G. Almeida ${ }^{1,2}$, Raquel D. Rufino ${ }^{2,3}$, Juliana M. Luna ${ }^{2,3}$, Valdemir A. Santos ${ }^{2,3}$ and Leonie Asfora Sarubbo ${ }^{2,3, *}$

1 Post-Graduate Program in Biotechnology, Federal Rural University of Pernambuco, CEP 52.171-900 Recife, PE, Brazil; E-Mails: ritaf78@gmail.com (R.C.F.S.S.); darne@buenomak.com.br (D.G.A.)

2 Center for Management of Technology and Innovation-CGTI, Rua da Praia, n.11, São José, CEP 50.020-550 Recife, PE, Brazil; E-Mails: raqueldrufino@yahoo.com.br (R.D.R.); julianamouraluna@gmail.com (J.M.L.); valdemir.alexandre@hotmail.com (V.A.S.)

3 Center for Sciences and Technology, Catholic University of Pernambuco, Rua do Príncipe, n. 526, Boa Vista, CEP 50.050-900 Recife, PE, Brazil

* Author to whom correspondence should be addressed; E-Mail: leonie@unicap.br; Tel.: +55-81-2119-4084; Fax: +55-81-2119-4000.

Received: 16 May 2014; in revised form: 26 June 2014 / Accepted: 7 July 2014 /

Published: 15 July 2014

\begin{abstract}
Petroleum hydrocarbons are important energy resources. However, petroleum is also a major pollutant of the environment. Contamination by oil and oil products has caused serious harm, and increasing attention has been paid to the development and implementation of innovative technologies for the removal of these contaminants. Biosurfactants have been extensively used in the remediation of water and soil, as well as in the main stages of the oil production chain, such as extraction, transportation, and storage. This diversity of applications is mainly due to advantages such as biodegradability, low toxicity and better functionality under extreme conditions in comparison to synthetic counterparts. Moreover, biosurfactants can be obtained with the use of agro-industrial waste as substrate, which helps reduce overall production costs. The present review describes the potential applications of biosurfactants in the oil industry and the remediation of environmental pollution caused by oil spills.
\end{abstract}

Keywords: surface tension; industrial wastes; patents; sustainable technologies 


\section{Introduction}

Petroleum is one of the most important energy resources and a raw material of the chemical industry. The world depends on oil and the use of oil as fuel has contributed to intensive economic development. Although petrochemical plants and oil refineries are beneficial to society, they produce a large amount of hazardous waste. Moreover, oil spills during exploration, transportation, and refining, have caused serious environmental problems [1-6].

The remediation of contaminated sites can be achieved by physicochemical or biological methods. Conventional physicochemical methods can rapidly remove the majority of spilled oil, but, in most cases, removal simply transfers contaminants from one environmental medium to another and can even produce toxic byproducts. Moreover, crude oil cannot be completely cleaned up with physicochemical methods. Thus, more attention is being given to biological alternatives [7,8]. Biosurfactants play an important role in remediation processes due to their efficacy as dispersion and remediation agents as well as their environmentally friendly characteristics, such as low toxicity and high biodegradability [9]. Indeed, biosurfactants have applications in different industrial processes as well as possible novel uses in the future and are expected to become known as multifunctional materials of the 21 st century [5]. Currently, the major market for biosurfactants is the petroleum industry, in which these compounds can be used in the cleanup of oils spills, the removal of oil residue from storage tanks, microbial-enhanced oil recovery, and the bioremediation of soil and water [3].

The diverse structures of biosurfactants have useful properties with industrial potential. The production of surfactants by microorganisms is performed to enhance both the bioavailability of nearly inaccessible substrates and survival under conditions of low moisture. Biosurfactant production generally requires a hydrophobic and hydrophilic carbon source in the culture medium. The process is economically and environmentally attractive when waste products are used [10,11].

This review addresses the potential roles and applications of biosurfactants, focusing on the petroleum industry and bioremediation processes. The key features of the microbial biosynthesis of biosurfactants, their physicochemical and bioactive properties and the use of industrial wastes as cost-effective alternatives for biosurfactant production are also summarized.

\section{Biosurfactants}

The advance of sustainable technologies has driven the search for natural, biodegradable compounds to remediate sites contaminated by hydrocarbons. This has led to the discovery of surfactants of a natural origin. Most of these surfactants are synthesized by living organisms, such as, saponins produced by plants, glycolipids produced by microorganisms, and bile salts produced by animals. Compounds with surfactant properties produced by microorganisms are denominated biosurfactants $[2,12]$.

Biosurfactants are mainly produced by aerobic microorganisms in aqueous media with a carbon source feedstock, such as carbohydrates, hydrocarbons, fats, and oils. It is believed that biosurfactants are secreted into the culture medium to assist in the growth of the microorganism by facilitating the translocation of insoluble substrates across cell membranes [13]. These compounds have amphipathic molecules with hydrophobic and hydrophilic portions that act between fluids of different polarities 
(oil/water and water/oil), allowing access to hydrophobic substrates and causing a reduction in surface tension, an increase in the area of contact of insoluble compounds (such as hydrocarbons) and the enhancement of the mobility, bioavailability, and biodegradation of such compounds [12]. The lipophilic moiety can be a protein or peptide with a high proportion of hydrophobic side chains or a hydrocarbon chain of a fatty acid with 10 to 18 carbon atoms, although fatty acids with a higher molecular weight have been reported. The hydrophilic moiety can be an ester, hydroxy, phosphate, carboxylate group, or sugar [13]. Biosurfactants are generally classified into low molecular-mass molecules, which efficiently lower surface and interfacial tensions, and high molecular-mass polymers, which are more effective as emulsion-stabilizing agents. The major classes of low-mass surfactants are glycolipids, lipopeptides, and phospholipids, whereas high-mass surfactants include polymeric and particulate surfactants [14].

Biosurfactants offer a number of advantages over chemical surfactants, such as biodegradability due to their simple chemical structure, environmental compatibility, low toxicity, which allows use in the cosmetic, pharmaceutical and food industry, high selectivity due to presence of specific functional groups, allowing specificity in the detoxification of specific pollutants, and activity under conditions of extreme temperatures, $\mathrm{pH}$ and salinity $[14,15]$. These traits contribute to the applicability of biosurfactants in different industries [16,17].

The fact that biosurfactants are characterized by a vast structural diversity and display a broad range of properties may explain why this group of molecules continues to pique scientific interest $[5,16,18]$. Due to their diverse industrial applications, many authors have filed for patents on biosurfactants. Indeed, patents have been issued for biosurfactant producing microbes, especially Pseudomonas spp., Acinetobacter spp., Bacillus spp., and Candida spp., types of biosurfactant, the production process and industrial applications [19]. Table 1, adapted from Sachdev and Cameotra [19], lists some of the important patents issued in recent years.

The economics of biosurfactant production merit particular attention. The total production of surfactants in 2012 was $\sim 12$ million tons, only 3.5 million tons of which were biosurfactants. Moreover, revenues from the bio-based portion of the market were US\$ 6.588 million [13]. However, the focus on sustainability and new environmental legislation has led to the search for natural surfactants as alternatives to existing products [13]. Industries are currently seeking to replace some or all chemical surfactants with sustainable biosurfactants [5], but the high production cost is a major drawback. A key factor governing the success of biosurfactant production is the development of an economical process that uses low-cost materials and offers high yield. Indeed, the choice of a low-cost substrate is important to the overall economics, as the substrate accounts for up to $50 \%$ of the final production cost. Fortunately, biosurfactants can be produced with economical, renewable resources, such as vegetable oils, distillery waste, and dairy waste [20].

Essentially agricultural countries, such as Brazil, have easy access to agro-industrial byproducts. Table 2 lists wastes and byproducts studied by Brazilian researchers to help reduce the cost of biosurfactant production. 
Table 1. Patents on biosurfactants produced by microorganisms.

\begin{tabular}{|c|c|c|c|c|}
\hline $\begin{array}{c}\text { Microorganism/Type } \\
\text { of Biosurfactant }\end{array}$ & $\begin{array}{l}\text { Patent } \\
\text { Holder }\end{array}$ & Title of Patent & Publication No. & $\begin{array}{c}\text { Publication } \\
\text { Date }\end{array}$ \\
\hline Sophorolipid producer & Borzeix F & $\begin{array}{c}\text { Sophorolipids as } \\
\text { stimulating agent of } \\
\text { dermal fibroblast } \\
\text { metabolism }\end{array}$ & US $6057302 \mathrm{~A}$ & 2 May 2000 \\
\hline Sophorolipid producer & $\begin{array}{l}\text { Borzeix F, } \\
\text { Concaix }\end{array}$ & $\begin{array}{l}\text { Use of sophorolipids } \\
\text { comprising diacetyl } \\
\text { lactones as agent for } \\
\text { stimulating skin } \\
\text { fibroblast metabolism }\end{array}$ & US 6596265 B1 & 22 July 2003 \\
\hline $\begin{array}{c}\text { New strains of } \\
\text { hydrocarbon-degrading } \\
\text { bacteria capable of } \\
\text { producing } \\
\text { biosurfactants }\end{array}$ & $\begin{array}{c}\text { Robin L. } \\
\text { Brigmon, } \\
\text { Sandra Story, } \\
\text { Denis Altman, } \\
\text { Christopher J. } \\
\text { Berry }\end{array}$ & $\begin{array}{l}\text { Surfactant biocatalyst } \\
\text { for remediation of } \\
\text { recalcitrant organics } \\
\text { and heavy metals }\end{array}$ & PI 0519962-0 A2 & 28 June 2005 \\
\hline Sophorolipid producer & $\begin{array}{l}\text { Gross RA, } \\
\text { Shah V, } \\
\text { Doncel GF }\end{array}$ & $\begin{array}{c}\text { Spermicidal and } \\
\text { virucidal properties of } \\
\text { various forms of } \\
\text { sophorolipids }\end{array}$ & WO 2005089522 A2 & $\begin{array}{c}29 \text { September } \\
2005\end{array}$ \\
\hline $\begin{array}{l}\text { C. albicans, } \\
\text { C. rugosa, } \\
\text { C. tropicalis, } \\
\text { C. lipolytica, } \\
\text { C. torulopsis }\end{array}$ & $\begin{array}{l}\text { Awada S, } \\
\text { Spendlove R, } \\
\text { Awada M }\end{array}$ & $\begin{array}{l}\text { Microbial } \\
\text { biosurfactants as agents } \\
\text { for controlling pests }\end{array}$ & US $20050266036 \mathrm{~A} 1$ & $\begin{array}{c}1 \text { December } \\
2005\end{array}$ \\
\hline $\begin{array}{c}\text { Pseudomonas } \\
\text { aeruginosa }\end{array}$ & $\begin{array}{c}\text { Silvanito } \\
\text { Alves } \\
\text { Barbosa, } \\
\text { Roberto } \\
\text { Rodrigues De } \\
\text { Souza } \\
\end{array}$ & $\begin{array}{l}\text { Biosurfactant } \\
\text { production for } \\
\text { development of } \\
\text { biodegradable } \\
\text { detergent }\end{array}$ & PI $1102592-1$ A2 & 16 May 2011 \\
\hline Sophorolipid producer & $\begin{array}{c}\text { Cox TF, } \\
\text { Crawford RJ, } \\
\text { Gregory LG, } \\
\text { Hosking SL, } \\
\text { Kotsakis } \\
\end{array}$ & $\begin{array}{l}\text { Mild to skin, foaming } \\
\text { detergent composition }\end{array}$ & WO2011120776 A1 & 6 October 2011 \\
\hline Streptomyces sp. & $\begin{array}{l}\text { Ana LF Porto, } \\
\text { Eduardo F } \\
\text { Santos, } \\
\text { Leonie A } \\
\text { Sarubbo }\end{array}$ & $\begin{array}{l}\text { Biosurfactant and } \\
\text { production process }\end{array}$ & PI 1105951-6 A2 & $\begin{array}{c}28 \text { November } \\
2011\end{array}$ \\
\hline
\end{tabular}


Table 1. Cont.

\begin{tabular}{|c|c|c|c|c|}
\hline $\begin{array}{c}\text { Microorganism/Type } \\
\text { of Biosurfactant }\end{array}$ & $\begin{array}{l}\text { Patent } \\
\text { Holder }\end{array}$ & Title of Patent & Publication No. & $\begin{array}{l}\text { Publication } \\
\text { Date }\end{array}$ \\
\hline $\begin{array}{c}\text { Candida } \\
\text { guilliermondii }\end{array}$ & $\begin{array}{c}\text { Leonie A } \\
\text { Sarubbo, } \\
\text { Valdemir A } \\
\text { Santos, } \\
\text { Raquel D } \\
\text { Rufino, } \\
\text { Juliana M } \\
\text { Luna }\end{array}$ & $\begin{array}{c}\text { Production process of } \\
\text { biosurfactant produced } \\
\text { by Candida } \\
\text { guilliermondii using } \\
\text { agro-industrial waste }\end{array}$ & BR102012023115 & $\begin{array}{c}13 \text { September } \\
2012\end{array}$ \\
\hline $\begin{array}{c}\text { Candida bombicola } \\
\text { ATCC } 2214\end{array}$ & $\begin{array}{l}\text { Soetaert W, } \\
\text { De MS, } \\
\text { Saerens K, } \\
\text { Roelants S, } \\
\text { Van BI }\end{array}$ & $\begin{array}{l}\text { Modified sophorolipid } \\
\text { production by yeast } \\
\text { strains and uses }\end{array}$ & EP $2580321 \mathrm{~A} 1$ & 17 April 2013 \\
\hline $\begin{array}{l}\text { Lipopeptide } \\
\text { producer }\end{array}$ & $\begin{array}{l}\text { X. Vecino, R. } \\
\text { Dvesa-Rey, } \\
\text { J.M. Cruz, } \\
\text { A.B. Moldes }\end{array}$ & $\begin{array}{c}\text { Method for separating } \\
\text { the surfactants present } \\
\text { in the washing liquors } \\
\text { of corn and uses }\end{array}$ & WO2014044876 A1 & 27 March 2014 \\
\hline
\end{tabular}

Table 2. Waste and byproducts used for biosurfactant production and respective producing microorganisms.

\begin{tabular}{ccc}
\hline Waste/by-Product & $\begin{array}{c}\text { Biosurfactant-Producing } \\
\text { Microorganism }\end{array}$ & Reference \\
\hline Canola waste frying oil and corn & Pseudomonas cepacia CCT6659 & {$[21]$} \\
steep liquor & Pseudomonas aeruginosa UCP0992 & {$[22]$} \\
Glycerol & Bacillus subtilis LAMI005 & {$[23]$} \\
Clarified cashew apple juice & Bacillus pumilus & {$[24]$} \\
Vinasse and waste frying oil & Bacillus subtilis LB5a & {$[25]$} \\
Cassava wastewater & Candida sphaerica UCP0995 & {$[26]$} \\
Soybean oil refinery residue and & & \\
corn steep liquor & Candida sphaerica UCP0995 & {$[27]$} \\
Ground-nut oil refinery residue and & Candida lipolytica UCP0988 & {$[15]$} \\
corn steep liquor & Candida glabrata UCP1002 & {$[28]$} \\
Animal fat and corn steep liquor & Candida tropicalis UCP0996 & {$[29]$} \\
Vegetable fat & Pseudomonas aeruginosa (P.A.) & {$[30]$} \\
Waste frying oil & &
\end{tabular}

\section{Biosurfactant-Producing Microorganisms}

A number of microorganisms, such as fungi, yeasts, and bacteria, feed on substances that are immiscible in water, producing and using a surface-active substance (biosurfactant) $[3,17]$. Among bacteria, the genus Pseudomonas is known for its capacity to produce extensive quantities of glycolipids. These biosurfactants are classified as rhamnolipids. Bacillus subtilis is 
another microorganism widely studied for biosurfactant production and is known for its efficiency in producing a lipopeptide with surface activity denominated surfactin or subtilisin [2,12,31-33]. Candida bombicola and Candida lipolytica are among the most commonly studied yeasts for the production of biosurfactants [13]. Table 3 offers a list microorganisms that produce biosurfactants [3,34].

Table 3. Main classes of biosurfactants and respective producer microorganisms.

\begin{tabular}{ll}
\hline Class/Type of Biosurfactant & Microorganisms \\
\hline Glycolipids & \\
Rhamnolipids & Pseudomonas aeruginosa \\
Sophorolipids & Torulopsis bombicola, . apicola \\
Trehalolipids & Rhodococcus erythropolis, Mycobacterium sp. \\
\hline Lipopeptides and lipoproteins & \\
Peptide-lipid & Bacillus licheniformis \\
Viscosin & Pseudomonas fluorescens \\
Serrawettin & Serratia marcenscens \\
Surfactin & Bacillus subtilis \\
Subtilisin & Bacillus subtilis \\
Gramicidin & Bacillus brevis \\
Polymyxin & Bacillus polymyxia \\
\hline Fatty acids, neutral lipids and phospholipids & \\
Fatty acid & Corynebacterium lepus \\
Neutral lipids & Nocardia erythropolis \\
Phospholipids & Thiobacillus thiooxidans \\
\hline Polymeric surfactants & \\
Emulsan & Acinetobacter calcoaceticus \\
Biodispersan & Acinetobacter calcoaceticus \\
Liposan & Candida lipolytica \\
Carbohydrate-lipid-protein & Pseudomonas fluorescens \\
Mannan-lipid-protein & Candida tropicalis \\
\hline Particulate surfactant & \\
Vesicles & Acinetobacter calcoaceticus \\
\hline
\end{tabular}

\section{Environmental Contamination by Oil Spills and Biosurfactant-Enhanced Remediation}

The release of contaminants, such as petroleum and petroleum byproducts, into the environment is one of the main causes of global pollution and has become a focus of great concern both in industrialized and developing countries due to the broad environmental distribution in soil, groundwater, and air $[18,35]$. The contamination sources are diverse: accidents during fuel transportation by ships and trucks; leakage from underground storage tanks that are subject to corrosion, such as gas stations; oil extraction and processing operations; and inadequate release of waste generated by industries that use oil byproducts in the production of plastics, solvents, pharmaceuticals, and cosmetics [16,36-38]. Half the world's oil production (around three billion tons/year) is transported by ship and hydrocarbon contamination levels in different marine ecosystems have increased due to accidents. The major hydrocarbon source in oceans comes from routine operations of ship washing, natural oil leakage on the sea bed, and accidents during oil exploration and transportation [2]. 
The media has consistently reported the leakage of thousands of tons of oil that contaminate seawater [39]. One of the most impacting spills occurred in November of 2011 on the Sedco 706 oil rig, operated by Chevron Brazil in Campos Bay (Rio de Janeiro, Brazil). A total of 5943 L leaked, covering $163 \mathrm{~km}^{2}$ [2]. Another of the largest oil spills in the world occurred in the Gulf of Mexico in 2010, following the explosion of an oil rig off the coast of the states of Louisiana and Mississippi (USA). After the sinking of the rig, the open ducts in the drilling area (depth of $1.5 \mathrm{kms}$ ) continued spewing oil into the sea for a three-month period before finally being capped. Official reports indicate the release of a thousand barrels of oil per day, with an estimated total of three to four million barrels of oil spilled, making this the largest environmental disaster in the history of the United States [6]. In July 2010, an oil spill of 1500 tons of crude oil caused serious environmental problems to the ocean and coast in Dalian, China [1]. In January 2000, more than 1.3 million L of heavy oil leaked from a refinery pipeline into Guanabara Bay in Rio de Janeiro, Brazil, causing extensive damage to preserved mangrove areas [40].

Over ten events of oil tankers with important wastes have occurred in Europe since 1967. The Prestige oil spill may be considered as one of the worst. The oil tanker Prestige, loaded with a cargo of 77,000 tons of heavy bunker oil ran into problems off the Galician coast (NW Spain) on 13 November 2002. After several days following an erratic path and spilling 19,000 tons, the tanker finally sank 130 miles west off the southern coast [41].

Large amounts of crude oil entering the marine environment, groundwater and soil can cause significant harm to resident organisms [8]. Petroleum is a hydrophobic hydrocarbon with negative effects on the structural and functional properties of cell membranes in living organisms, offering considerable risk of contamination in both marine and terrestrial ecosystems [3]. When in contact with water, oil and its byproducts spread and form a thin layer on the surface that prevents gas exchange between the air and water, blocking the passage of sunlight and impeding the respiration and photosynthesis process. Thus, hydrocarbon waste impacts phytoplankton communities, causing a fundamental breakdown of the food chain $[42,43]$. The potential threat to human health posed by hydrocarbons is linked to the physical and chemical properties of these compounds, which are absorbed by the skin and quickly spread through the organism if ingested or inhaled $[44,45]$.

The most common role of biosurfactants is to enhance the dispersal of contaminants in the aqueous phase and increase the bioavailability of the hydrophobic substrate to microorganisms, with subsequent removal of such pollutants through biodegradation $[12,46]$. Numerous examples demonstrate the potential application of biosurfactants in environmental decontamination. Sobrinho et al. [27] tested a biosurfactant produced by Candida sphaerica for the removal of motor oil from soil and seawater and found removal rates of $75 \%$ and $92 \%$ from clay and silty soil, respectively; in tests carried out with seawater, the biosurfactant exhibited an oil spreading efficiency of $75 \%$, demonstrating its potential for application as an adjuvant in biotechnological processes of environmental decontamination. Batista et al. [29] investigated the application of a biosurfactant produced by Candida tropicalis for removing motor oil from sand and found removal rates of $78 \%$ to $97 \%$, demonstrating considerable potential with regard to soil bioremediation. Gusmão et al. [28] investigated the application of a crude biosurfactant produced by Candida glabrata UCP1002 in a soil-water-hydrophobic contaminant system and found a removal rate as high as $92.6 \%$. Luna et al. [26] evaluated a new biosurfactant, denominated Lunasan, produced by Candida sphaerica UCP 0995. This biosurfactant removed 95\% 
of motor oil adsorbed to sand, demonstrating considerable potential for use in bioremediation processes. The remediation of hydrocarbons contaminated soils using a cell-bound biosurfactant from Lactobacillus pentosus has been also described [47,48]. Table 4 offers a list of different types of biosurfactants and their producing microorganisms with potential applications in the bioremediation of oil-polluted environments [10,49].

Table 4. Biosurfactants, producing microorganisms and uses in the bioremediation of oil-contaminated environments.

\begin{tabular}{|c|c|c|}
\hline Microorganisms & Type of Biosurfactant & Applications \\
\hline Rhodococcus erythropolis 3C-9 & $\begin{array}{l}\text { Glucolipid and } \\
\text { trehalose lipid }\end{array}$ & Oil spill cleanup operations \\
\hline Pseudomonas aeruginosa $\mathrm{S} 2$ & Rhamnolipid & Bioremediation of oil-contaminated sites \\
\hline Rhodococcus sp. TW53 & Lipopeptide & Bioremediation of marine oil pollution. \\
\hline R. wratislaviensis $\mathrm{BN} 38$ & Glycolipid & Bioremediation applications \\
\hline Bacillus subtilis BS5 & Lipopeptide & $\begin{array}{l}\text { Bioremediation of } \\
\text { hydrocarbon-contaminated sites }\end{array}$ \\
\hline Azotobacter chroococcum & Lipopeptide & Environmental applications. \\
\hline Pseudomonas aeruginosa BS20 & Rhamnolipid & $\begin{array}{l}\text { Bioremediation of } \\
\text { hydrocarbon-contaminated sites }\end{array}$ \\
\hline Micrococcus luteus BN56 & Trehalose tetraester & $\begin{array}{l}\text { Bioremediation of oil-contaminated } \\
\text { environments }\end{array}$ \\
\hline Nocardiopsis alba MSA10 & Lipopeptide & Bioremediation \\
\hline Pseudoxanthomonas sp. PNK-04 & Rhamnolipid & Environmental applications \\
\hline Pseudomonas alcaligenes & Rhamnolipid & Environmental applications \\
\hline Nocardiopsis lucentensis MSA04 & Glycolipid & Bioremediation of marine environment \\
\hline Calyptogena soyoae & Mannosylerythritol lipid & Bioremediation of marine environment \\
\hline Pseudozyma hubeiensis & Glycolipid & Bioremediation of marine oil pollution \\
\hline Pseudomonas cepacia СCТ6659 & Rhamnolipid & $\begin{array}{l}\text { Bioremediation of marine and } \\
\text { soil environments }\end{array}$ \\
\hline Candida bombicola & Sophorolipids & Environmental applications \\
\hline C. glabrata UCP1002 & $\begin{array}{l}\text { Protein-carboydrate-lipid } \\
\text { complex }\end{array}$ & Oil recovery from sand \\
\hline C. lipolytica UCP0988 & Sophorolipids & Oil recovery \\
\hline C. lipolytica UCP0988 & Sophorolipids & Oil removal \\
\hline C. sphaerica UCP0995 & $\begin{array}{l}\text { Protein-carboydrate-lipid } \\
\text { complex }\end{array}$ & Removal of oil from sand \\
\hline C. lipolytica UCP0988 & Sophorolipids & Control of environmental oil pollution \\
\hline C. sphaerica UCP0995 & $\begin{array}{l}\text { Protein-carboydrate-lipid } \\
\text { complex }\end{array}$ & Bioremediation processes \\
\hline C. glabrata UCP1002 & $\begin{array}{l}\text { Protein-carboydrate-lipid } \\
\text { complex }\end{array}$ & Oil removal \\
\hline C. guilliermondii UCP0992 & Glycolipid complex & $\begin{array}{l}\text { Removal of petroleum derivate motor oil } \\
\text { from sand }\end{array}$ \\
\hline C. tropicalis UCP0996 & $\begin{array}{l}\text { Protein-carboydrate-lipid } \\
\text { complex }\end{array}$ & $\begin{array}{l}\text { Removal of petroleum and motor oil } \\
\text { adsorbed to sand }\end{array}$ \\
\hline C. lipolytica UCP0988 & Sophorolipids & $\begin{array}{l}\text { Removal of petroleum and motor oil } \\
\text { adsorbed to sand }\end{array}$ \\
\hline C. sphaerica UCP0995 & $\begin{array}{l}\text { Protein-carboydrate-lipid } \\
\text { complex }\end{array}$ & Oil removal \\
\hline
\end{tabular}




\section{Application of Biosurfactants in the Petroleum Industry}

Petroleum is one of the major energy sources. The energy demand in the world indicates a $1.7 \%$ increase in the number of barrels of oil produced per year, between 2000 and 2030, while consumption is expected to reach 15.3 billion tons of oil per year. Oil reserves allow meeting the world's demand for approximately 40 years if current levels of consumption are maintained [45,50,51]. It is therefore important to develop technologies that allow the efficient use of this resource. According to the International Energy Agency, petroleum production is steadily moving toward unconventional crude oils, such as heavy and extra-heavy oils rather than medium and light oils. Heavy and extra-heavy crude oils represent at least one half of recoverable oil resources in countries such as Canada, China, Mexico, Venezuela, and the USA [52].

In the petroleum industry, biosurfactants have been applied effectively for the exploration of heavy oil, offering advantages over their synthetic counterparts throughout the entire petroleum processing chain (extraction, transportation and storage). Biosurfactants are used in microbial-enhanced oil recovery, the cleaning of contaminated vessels and to facilitate the transportation of heavy crude oil by pipeline [53,54]. Table 5 offers a list of biosurfactant applications in the oil industry [53].

Table 5. Common applications of biosurfactants in the petroleum industry.

\begin{tabular}{cc}
\hline Step in Petroleum Production Chain & Applications \\
\hline Extraction & Reservoir wettability modification \\
& Oil viscosity reduction \\
& Drilling mud \\
& Paraffin/asphalt deposition control \\
Transportation & Enhanced oil displacement \\
& Oil viscosity reduction \\
\hline Oil tank/container cleaning & Oil viscosity reduction \\
& Oil emulsion stabilization \\
& Paraffin/asphalt deposition \\
\hline & Oil viscosity reduction \\
& Oily sludge emulsification \\
\end{tabular}

\subsection{Extraction of Crude Oil from Reservoirs}

Several enhanced oil recovery processes are currently employed worldwide: thermal, chemical, physical, etc. [55]. However, these processes are very expensive as well as environmentally harmful. Thus, the search for alternative, cost-effective, eco-friendly alternatives to the chemical and thermal enhanced oil recovery methods is necessary. A number of biotechnology-based processes have been proposed to increase oil production in the current energy shortage [56]. Biosurfactants have applications in this realm, as these natural compounds improve the mobilization of hydrocarbons, thereby enhancing the recovery of crude oil from reservoirs in a process denominated microbial-enhanced oil recovery (MEOR) [57].

MEOR consists of the tertiary recovery of oil in which microorganisms or their metabolic products are used to recover residual oil. Microorganisms produce polymers and biosurfactants, which reduce 
oil-rock surface tension by diminishing the capillary forces that impede the movement of oil through the pores of rock. Biosurfactants also aid in the emulsification and breakdown of oil film in rock. MEOR involves different strategies, such as the injection of microorganisms that produce biosurfactants into the reservoir and subsequent spread in situ, the injection of nutrients into the reservoir to stimulate the growth of wild microorganisms that produce biosurfactants or the further production of biosurfactants in reactors and subsequent injection into the reservoir [31]. These processes enhance oil recovery from a depleted reservoir, thereby extending the life of the reservoir. MEOR is less-expensive in comparison to chemically-enhanced oil recovery, as microorganisms produce efficient products out of low-cost substrates or raw materials [58].

\subsection{Transport of Crude Oil by Pipelines}

Crude oil often needs to be transported over long distances from the extraction fields to refineries. The transportation of heavy and extra-heavy crude oil entails operational difficulties that limit its economic viability. The major problems are low flowability due to the high degree of viscosity and asphaltene content in heavy crude oil, which leads to inconveniences, such as the deposition of asphaltenes and/or paraffins as well as a drop in pressure that can cause plugging problems in the pipeline [52,57]. Asphaltenes precipitate in metal pipelines and in presence of ferric ions combined with acidic conditions, forming a solid denominated "asphaltene mud", which deposits in the pipeline and obstructs the free flow of crude oil. Solvents, such as toluene and xylene, are applied to dissolve this type of mud, which increases the production cost and generates highly toxic waste residue [53].

A promising technology involving the production of a stable oil-in-water emulsion that facilitates oil mobility has been recently developed. Biosurfactant-based emulsifiers (bioemulsifiers) are particularly suitable for this application. Bioemulsifiers are high-molecular weight surfactants with different properties in comparison to glycolipids and lipopeptides. These products are not effective at reducing interfacial tensions, but have an excellent capacity to stabilize oil-in-water emulsions. Due to the high number of reactive groups in the molecule, bioemulsifiers bind tightly to oil droplets and form an effective barrier that prevents drop coalescence [57]. Emulsan is the most powerful bioemulsifier and has potential applications in the petroleum industry, including the formation of heavy oil-water emulsions for viscosity reduction during pipeline transport $[53,57]$.

\subsection{Oil Storage Tank Cleaning}

Large amounts of crude oil are moved daily, distributed to refineries and placed in storage tanks. The maintenance of these tanks requires periodic washing. However, waste and heavy oil fractions that build up at the bottom and on the walls of storage tanks are highly viscous and become solid deposits that cannot be removed with conventional pumping. The removal of this material requires washing with solvents and manual cleaning, which is a hazardous, time-consuming, labor intensive, expensive procedure, as cleaning operations may include hot water spraying, solvent liquefaction and subsequent land waste disposal [57,59].

The use of microbial biosurfactants is an alternative cleaning procedure to decrease the viscosity of sludge and oil deposits through the formation of an oil-in-water emulsion that facilitates the pumping of waste. Moreover, this process allows the recovery of crude oil when the emulsion is broken. 
Matsui et al. [59] investigated the treatment of oil tank bottom sludge with a novel biosurfactant, JE1058BS, produced by the actinomycete Gordonia sp. Dispersion activity was greater than that achieved with a chemical or plant-derived surfactant and the biosurfactant remained stable for at least three weeks. Diab and El Din [60] evaluated the effect of the supernatant from P.aeruginosa SH 29 applied to the cleaning of oil-contaminated vessels. The oil was recovered from the bottom and walls of the vessels in just fifteen minutes and floated on the supernatant as a distinct phase. According to the authors, this indicates that the biosurfactant in the sterilized supernatant of P.aeruginosa SH 29 can be used directly for cleaning oil storage tanks and other vessels used for the transportation and storage of crude oil. Rocha and Silva et al. [6] tested the potential of an isolated biosurfactant from Pseudomonas cepacia CCT6659 for cleaning beaker walls contaminated with a layer of oil and found a removal rate of $80 \%$, which suggests the applicability of this biosurfactant in the cleaning of storage tanks.

\section{Toxicity of (Bio)Surfactants and Dispersants on Organisms in the Bioremediation Process}

The toxicity of biosurfactants in the environment is not well known. Edwards et al. [61], in a comparison of toxicity of three synthetic surfactants and three microbial surfactants, concluded that the biosurfactants were less toxic than the synthetic surfactants to some invertebrate species. However, the environmental risks posed by biosurfactants, evaluated through microbial community composition analysis have not been sufficiently evaluated [62].

The lower toxicity and higher biodegradability of biological surfactants compared to their chemical counterparts is the main reason for their high acceptability. However, these features are often assumed as only direct consequence of their natural origin. For these reasons, the environmental features of novel biosurfactants should be carefully considered and investigated before their release into the environment [63].

While the microbial toxicity of (bio)surfactants is a possible cause of bioremediation inhibition, many (bio)surfactants are not toxic to microorganisms at concentrations near their CMC values [64]. Another possible cause of a reduced rate of bioremediation in the presence of (bio)surfactant is due to increased toxicity of the hydrophobic contaminant due to its increased (pseudo)solubility. (Bio)surfactants increase the apparent aqueous solubility of hydrophobic substrates. In addition, some (bio)surfactants or pseudosolubilized contaminants may exhibit selective toxicity toward specific pure cultures but may have a limited inhibitory impact in a remediation system involving a diverse indigenous microbial population [65].

Regarding the use of dispersants, several classes of these chemical agents are employed for environmental mitigation and cleanup; however, these industrial chemicals may present risks to aquatic organisms individually and when mixed with oil $[66,67]$.

The U.S. Clean Water Act and Oil Pollution Act of 1990 requires the maintenance of a National Oil and Hazardous Substances Pollution Contingency Plan (NCP) for response to oil spills that identifies specific commercial products used for control of oil discharges and the quantities and water bodies in which the products may be used [68]. These products consist of dispersants, surface washing agents, surface collecting agents, bioremediation agents, and other miscellaneous oil spill control agents. Under the NCP, the U.S. Environmental Protection Agency has statutory responsibility for obtaining 
toxicity and efficacy information from the manufacturers before placing a dispersant on the National Product Schedule [67,68]. Fourteen dispersants are listed on the U.S. Environmental Protection Agency (U.S. EPA). Although the exact compositions of most commercially available oil dispersants are proprietary, they typically contain a high percentage of one or more uncharged or charged anionic surfactants of different solubility [68].

Probabilistic hazard assessment approaches including Chemical Toxicity Distributions (CTDs) may be useful as an initial step toward prioritizing environmental hazards from the use of dispersants. The CTD approach to two acute toxicity datasets (NCP - the contingency plan dataset and DHOS - a subset of NCP listed dispersants reevaluated subsequent to the Deepwater Horizon oil spill) contain median lethal concentration (LC50) values for dispersants alone and dispersant: oil mixtures, in two standard marine test species, Menidia beryllina and Mysidopsis bahia. These CTDs suggest that dispersants alone are generally less toxic than oil. In contrast, most dispersant: oil mixtures are more toxic than oil alone [66].

Rigorous toxicological comparison of untreated and dispersant-treated oil is complicated by the fact that when oil, seawater, and dispersants are mixed, a complex multiphase system results. In this complex system, aquatic organisms can be exposed to many toxicants, in many forms, which can have several modes of action. Moreover, chemical dispersion of oil can yield: (1) dissolved petroleum hydrocarbons; (2) dissolved dispersant surfactants; (3) mixed droplets of bulk oil and surfactants (often in micellar form); and (4) nonmicellar, particulate bulk oil [67].

A second important issue for determining the effects of dispersants, is the separate and combined toxicity of the dispersant and the crude oil droplets. Toxicity became an important issue in the late 1960s and early 1970s when application of toxic products resulted in substantial loss of sea life [67]. Since that time, dispersants have been formulated to minimize toxicity to aquatic organisms. For example, the LC50 values of dispersants used in the early 1970s ranged from about 5 to $50 \mathrm{mg} / \mathrm{L}$ to the rainbow trout in $96 \mathrm{~h}$ exposures. In contrast, LC50s for dispersants available today vary from 200 to $500 \mathrm{mg} / \mathrm{L}$ and contain a mixture of surfactants and a less toxic solvent. The U.S. EPA uses a five-step scale of toxicity categories to classify pesticides based on their acute toxicity to aquatic organisms [69]. Nonetheless, use of oil dispersants remains a controversial countermeasure to minimize the impact of oil spills $[67,68]$.

Because the purpose of a dispersant is to facilitate the acceleration of natural attenuation and dilution of spilled oil, the aquatic toxicity of the dispersant: oil mixture is an important consideration. This further complicates a comparative toxicity evaluation, because the course of toxicity in a mixture may be unknown and potentially different for each dispersant. Therefore, although the presence of polycyclic aromatic hydrocarbons does not represent the only factor in determining oil toxicity, evidence links the increased presence of polycyclic aromatic hydrocarbons in chemically dispersed oils to increased toxicity to aquatic organisms $[68,70]$.

The general proposal of toxicity tests is to establish the potential impact of chemicals on the biota of a given environment. The information acquired can be used to regulate use of chemical substances and evaluate the necessity for treatment after their release to the environment [71,72]. An understanding of the factors that contribute to the toxicity of surfactants is necessary to interpret results of toxicity tests of this class of compounds [72]. The most important factor to consider is chemical structure. Since several years, all studies have emphasized the benefits of using rapid, sensitive, reproducible and 
cost-effective bacterial assays for toxicity screening and assessment [73]. Microorganisms are useful in ecotoxicity testing because they may be evaluated over a short time and they occupy trophic levels in which bioaccumulation and/or bioconcentration are potential problems [74]. Bacterial toxicity tests measure a wide variety of endpoints including mutagenicity tests [75], population growth [76], $\mathrm{CO}_{2}$ production [77], enzyme biosynthesis [78], glucose mineralization [79], and bioluminescence inhibition [80].

Several tests have been used to evaluate the toxicity of chemical and biological surfactants on various organisms. The lethal concentration $\left(\mathrm{LC}_{50}\right)$ is a method that evaluates the rate of population mortality of a species and indicates that the higher the concentration, the lower the toxicity of the surfactant $[61,81]$. The germination index (GI) it is another method which combines measures of relative vegetable seed germination and relative root elongation to evaluate the toxicity of biosurfactants. The GI value of $80 \%$ has been used as an indicator of the disappearance of phytotoxicity $[6,18,20,22]$.

Table 6 lists toxicity values of (bio)surfactants, dispersants, crude oils and dispersant/crude oil mixtures to vegetables and organisms collected from the literature.

Table 6. Results of toxicity tests of (bio)surfactants, dispersants, crude oils, and dispersant/crude oil mixtures to vegetables and organisms.

\begin{tabular}{|c|c|c|c|}
\hline Test Compound & Organisms/Vegetables Test & Toxicity & References \\
\hline \multicolumn{4}{|l|}{ Biosurfactants } \\
\hline Emulsan & Mysidopsis bahia & $\mathrm{LC}_{50}(200 \mathrm{mg} / \mathrm{L})$ & [61] \\
\hline Emulsan & Menidia beryllina & $\mathrm{LC}_{50}(300 \mathrm{mg} / \mathrm{L})$ & [61] \\
\hline $\begin{array}{c}\text { Candida sphaerica } \mathrm{UCP} \\
0995 \text { biosurfactant }\end{array}$ & Brassica oleracea & $86 \%$ GI & [81] \\
\hline $\begin{array}{c}\text { Candida sphaerica UCP } \\
0995 \text { biosurfactant }\end{array}$ & Artemia salina & $\mathrm{LC}_{50}(600 \mathrm{mg} / \mathrm{L})$ & [81] \\
\hline $\begin{array}{c}\text { Candida sphaerica UCP } \\
0995 \text { biosurfactant }\end{array}$ & Brassica oleracea & no toxicity & [18] \\
\hline $\begin{array}{c}\text { Candida sphaerica UCP } \\
0995 \text { biosurfactant }\end{array}$ & Artemia salina & no toxicity & [18] \\
\hline $\begin{array}{c}\text { Candida lipolytica UCP } \\
0988 \text { biosurfactant }\end{array}$ & Brassica oleracea & no toxicity & [20] \\
\hline $\begin{array}{c}\text { Candida lipolytica UCP } \\
0988 \text { biosurfactant }\end{array}$ & Artemia salina & no toxicity & [20] \\
\hline $\begin{array}{c}\text { Pseudomonas aeruginosa UCP } \\
0992 \text { biosurfactant }\end{array}$ & Brassica oleracea & $80 \%$ GI & [22] \\
\hline $\begin{array}{c}\text { Pseudomonas aeruginosa UCP } \\
0992 \text { biosurfactant }\end{array}$ & Artemia salina & $\mathrm{LC}_{50}(525 \mathrm{mg} / \mathrm{L})$ & [22] \\
\hline
\end{tabular}


Table 6. Cont.

\begin{tabular}{|c|c|c|c|}
\hline Test Compound & Organisms/Vegetables Test & Toxicity & References \\
\hline \multicolumn{4}{|l|}{ Emulsifiers/Dispersing agents } \\
\hline Dodecylbenzene sulfonate/LAS & Dugesia japonica & $\mathrm{LC}_{50}(1.45 \mathrm{mg} / \mathrm{L})$ & [82] \\
\hline Lauryl sulfate/SDS & Dugesia japonica & $\mathrm{LC}_{50}(0.36 \mathrm{mg} / \mathrm{L})$ & [82] \\
\hline Triton X-100 & Mysidopsis bahia & $\mathrm{LC}_{50}(3.3 \mathrm{mg} / \mathrm{L})$ & [61] \\
\hline Triton X-100 & Menidia beryllina & $\mathrm{LC}_{50}(2.5 \mathrm{mg} / \mathrm{L})$ & [61] \\
\hline Lauryl sulfate/SDS & Americamysis bahia & $\mathrm{LC}_{50}(18-23 \mathrm{mg} / \mathrm{L})$ & [68] \\
\hline Lauryl sulfate/SDS & Menidia beryllina & $\mathrm{LC}_{50}(10 \mathrm{mg} / \mathrm{L})$ & [68] \\
\hline \multicolumn{4}{|l|}{ Oil spill dispersants } \\
\hline Corexit 9500 & Mysidopsis bahia & $\mathrm{LC}_{50}(13.4 \mathrm{mg} / \mathrm{L})$ & [61] \\
\hline Corexit 9500 & Menidia beryllina & $\mathrm{LC}_{50}(75.7 \mathrm{mg} / \mathrm{L})$ & [61] \\
\hline Corexit 9500 & Porites astreoides & $13 \%$ surviving & [83] \\
\hline Corexit 9500 & Montastraea faveolata & $0 \%$ surviving & [83] \\
\hline Corexit 9500 & Americamysis bahia & $42(\mathrm{mg} / \mathrm{L})$ & [68] \\
\hline Corexit 9500 & Menidia beryllina & $130(\mathrm{mg} / \mathrm{L})$ & [68] \\
\hline Corexit 9500 & Brachionus plicatilis & $\mathrm{LC}_{50}(0.447 \mathrm{mg} / \mathrm{L})$ & [67] \\
\hline Corexit 9500 & Brachionus manjavacas & $\mathrm{LC}_{50}(14.2 \mathrm{mg} / \mathrm{L})$ & [67] \\
\hline \multicolumn{4}{|l|}{ Crude oils } \\
\hline BP Horizon source oil & Porites astreoides & $67 \%$ surviving & [83] \\
\hline BP Horizon source oil & Montastraea faveolata & $27 \%$ surviving & [83] \\
\hline Louisiana sweet crude oil & Americamysis bahia & $\mathrm{LC}_{50}(2.7 \mathrm{mg} / \mathrm{L})$ & [68] \\
\hline Louisiana sweet crude oil & Menidia beryllina & $\mathrm{LC}_{50}(3.5 \mathrm{mg} / \mathrm{L})$ & {$[68]$} \\
\hline Macondo sweet crude oil & Brachionus plicatilis & $\mathrm{LC}_{50}(2.47 \mathrm{mg} / \mathrm{L})$ & [67] \\
\hline Macondo sweet crude oil & Brachionus sp. & $\mathrm{LC}_{50}(19.3 \mathrm{mg} / \mathrm{L})$ & [67] \\
\hline \multicolumn{4}{|l|}{ Dispersant/oil mixtures } \\
\hline $\begin{array}{l}\text { Corexit 9500/BP } \\
\text { Horizon source oil }\end{array}$ & Porites astreoides & $67 \%$ surviving & [83] \\
\hline $\begin{array}{l}\text { Corexit 9500/BP } \\
\text { Horizon source oil }\end{array}$ & Montastraea faveolata & $20 \%$ surviving & [83] \\
\hline $\begin{array}{c}\text { Corexit 9500/Louisiana sweet } \\
\text { crude oil }\end{array}$ & Americamysis bahia & $\mathrm{LC}_{50}(5.4 \mathrm{mg} / \mathrm{L})$ & {$[68]$} \\
\hline $\begin{array}{c}\text { Corexit 9500/Louisiana sweet } \\
\text { crude oil }\end{array}$ & Menidia beryllina & $\mathrm{LC}_{50}(7.6 \mathrm{mg} / \mathrm{L})$ & {$[68]$} \\
\hline $\begin{array}{c}\text { 1:10 Corexit 9500/Macondo } \\
\text { sweet crude oil }\end{array}$ & Brachionus manjavacas & $0.21(\mathrm{mg} / \mathrm{L})$ & {$[67]$} \\
\hline $\begin{array}{l}\text { 1:50 Corexit 9500/Macondo } \\
\text { sweet crude oil }\end{array}$ & Brachionus manjavacas & $0.23(\mathrm{mg} / \mathrm{L})$ & [67] \\
\hline
\end{tabular}

GI: germination index; $\mathrm{LC}_{50}$ : concentration lethal to $50 \%$ of the test species.

\section{Conclusions}

This review provided information on the application of biosurfactants as a promising alternative in the petroleum industry and the bioremediation of oil spills. Since biosurfactants are not yet competitive with chemical surfactants from the economic standpoint, a more thorough investigation of biosurfactant production from agro-industrial waste is needed to reduce the production cost and allow the large-scale 
production of these natural compounds. The versatility and efficiency demonstrated in the application of biosurfactants in the oil production chain and the removal of hydrophobic contaminants make these compounds promising biomolecules.

\section{Acknowledgments}

This study was financed by the Brazilian fostering agencies Foundation for the Support of Science and Technology of the State of Pernambuco (FACEPE), Thermoelectric of Pernambuco (TERMOPE), National Agency of Electric Energy (ANEEL), National Council for Scientific and Technological Development $(\mathrm{CNPq})$ and Coordination for the Improvement of Higher Level Education Personnel (CAPES). The authors are grateful to the laboratories of the Center for Sciences and Technology of the Universidade Católica de Pernambuco, Brazil.

\section{Author Contributions}

Proposed the theoretical frame: Leonie Asfora Sarubbo. Wrote the paper: Rita de Cássia F. S. Silva, Darne G. Almeida, Raquel D. Rufino, Juliana M. Luna, Valdemir A. Santos and Leonie Asfora Sarubbo.

\section{Conflicts of Interest}

The authors declare no conflict of interest.

\section{References}

1. Zhang, Z.; Hou, Z.; Yang, C.; Ma, C.; Tao, F.; Xu, P. Degradation of n-alkanes and polycyclic aromatic hydrocarbons in petroleum by a newly isolated Pseudomonas aeruginosa DQ8. Bioresour. Technol. 2011, 102, 4111-4116.

2. Souza, E.C.; Vessoni-Penna, T.C.; Souza Oliveira, R.P. Biosurfactant-enhanced hydrocarbon bioremediation: An overview. Int. Biodeterior. Biodegrad. 2014, 89, 88-94.

3. Sobrinho, H.B.; Luna, J.M.; Rufino, R.D.; Porto, A.L.F.; Sarubbo, L.A. Biosurfactants: Classification, properties and environmental applications. In Recent Developments in Biotechnology, 1st ed.; Studium Press LLC: Houston, TX, USA, 2013; Volume 11, pp. 1-29.

4. Franzetti, A.; Caredda, P.; Ruggeri, C.; la Colla, P.; Tamburini, E.; Papacchini, M.; Bestetti, G. Potential applications of surface active compounds by Gordonia sp. strain BS29 in soil remediation technologies. Chemosphere 2009, 75, 810-807.

5. Marchant, R.; Banat, I.M. Microbial biosurfactants: Challenges and opportunities for future exploitation. Trends Biotechnol. 2012, 11, 558-565.

6. Rocha e Silva, N.M.P.; Rufino, R.D.; Luna, J.M.; Santos, V.A.; Sarubbo, L.A. Screening of Pseudomonas species for biosurfactant production using low-cost substrates. Biocatal. Agric. Biotechnol. 2013, 3, 132-139.

7. Malik, Z.A.; Ahmed, S. Degradation of petroleum hydrocarbons by oil field isolated bacterial consortium. Afr. J. Biotechnol. 2012, 11, 650-658.

8. Lin, M.; Yuhua, L.; Weiwei, C.; Hui, W.; Xiaoke, H. Use of bacteria-immobilized cotton fiUse to absorb and degrade crude oil. Int. Biodeterior. Biodegrad. 2014, 88, 8-12. 
9. Silva, E.J.; Rocha e Silva, N.M.P.; Rufino, R.D.; Luna, J.M.; Silva, R.O.; Sarubbo, L.A. Characterization of a biosurfactant produced by Pseudomonas cepacia CCT6659 in the presence of industrial wastes and its application in the biodegradation of hydrophobic compounds in soil. Colloids Surf. B Biointerfaces 2014, 117, 36-41.

10. Makkar, R.S.; Cameotra, S.S.; Banat, I.M. Advances in utilization of renewable substrates for biosurfactant production. Appl. Microbiol. Biotechnol. 2011, 1, 1-5.

11. Dziegielewska, E.; Adamczak, M. Evaluation of wast products in the synthesis of surfactants by yeasts. Chem. Pap. 2013, 67, 1113-1122.

12. Aparna, A.; Srinikethan, G.; Hedge, S. Effect of addition of biosurfactant produced by Pseudomonas ssp. on biodegradation of crude oil. In International Proceedings of Chemical, Biological \& Environmental Engineering. Proceedings of the 2nd International Proceedings of Chemical, Singapore, Singapore, 26-28 February 2011; Volume 6, pp. 71-75.

13. Campos, J.M.; Stamford, T.L.M.; Sarubbo, L.A.; Luna, J.M.; Rufino, R.D.; Banat, I.M. Microbial biosurfactants as additives for food industries. Biotechnol. Prog. 2013, 29, 1097-1108.

14. Kapadia, S.G.; Yagnik, B.N. Current trend and potential for microbial biosurfactants. Asian J. Exp. Biol. Sci. 2013, 4, 1-8.

15. Santos, D.K.F.; Rufino, R.D.; Luna, J.M.; Santos, V.A.; Salgueiro, A.A.; Sarubbo, L.A. Synthesis and evaluation of biosurfactant produced by Candida lipolytica using animal fat and corn steep liquor. J. Pet. Sci. Eng. 2013, 105, 43-50.

16. Lawniczak, L.; Marecik, R.; Chrzanowski, L. Contributions of biosurfactants to natural or induced bioremediation. Appl. Microbiol. Biotechnol. 2013, 97, 2327-2339.

17. Banat, I.M.; Franzetti, A.; Gandolfi, I.; Bestetti, G.; Martinotti, M.G.; Fracchia, L.; Smyth, T.J.; Marchant, R. Microbial biosurfactants production, applications. Appl. Microbiol. Biotechnol. 2010, $87,427-444$.

18. Luna, J.M.; Rufino, R.D.; Sarubbo, L.A.; Campos-Takaki, G.M. Characterisation, surface properties and biological activity of a biosurfactant produced from industrial waste by Candida sphaerica UCP0995 for application in the petroleum industry. Colloids Surf. B Biointerfaces 2013, 102, 202-209.

19. Sachdev, D.P.; Cameotra, S.S. Biosurfactants in agriculture. Appl. Microbiol. Biotechnol. 2013, 97, 1005-1016.

20. Rufino, R.D.; Luna, J.M.; Campos Takaki, G.M.; Sarubbo, L.A. Characterization and properties of the biosurfactant produced by Candida lipolytica UCP 0988. Electron. J. Biotechnol. 2014, 17, 34-38.

21. Silva, R.C.F.S.; Rufino, R.D.; Luna, J.M.; Farias, C.B.B.; Filho, H.J.B.; Santos, V.A.; Sarubbo, L.A. Enhancement of Biosurfactant Production from Pseudomonas cepacia CCT6659 Through Optimisation of Nutritional Parameters Using Response Surface Methodology. Tenside Surf. Det. 2013, 50, 137-142.

22. Silva, S.N.R.L.; Farias, C.B.B.; Rufino, R.D.; Luna, J.M.; Sarubbo, L.A. Glycerol as substrate for the production of biosurfactant by Pseudomonas aeruginosa UCP0992. Colloids Surf. B Biointerfaces 2010, 79, 174-183.

23. Oliveira, J.G.; Garcia-Cruz, C.H. Properties of a biosurfactant produced by Bacillus pumilus using vinasse and waste frying oil as alternative carbon sources. Braz. Arch. Biol. Technol. 2013, 56, $155-160$. 
24. Oliveira, D.W.F.; Franc, I.W.L.; Félix, A.K.N.; Martins, J.J.L.; Giroa, M.E.A.; Melo, V.M.M.; Alves, L.R.B.G. Kinetic study of biosurfactant production by Bacillus subtilis LAMI005 grown in clarified cashew apple juice. Colloids Surf. B Biointerfaces 2013, 101, 34-43.

25. Barros, F.F.C.; Quadros, C.P.; Pastore, G.M. Propriedades emulsificantes e estabilidade do biossurfactante produzido por Bacillus subtilis em manipueira. Cienc. Tecnol. Aliment. 2008, 28, 979-985.

26. Luna, J.M.; Rufino, R.D.; Sarubbo, L.A.; Rodrigues, L.R.M.; Teixeira, J.A.C.; Campos-Takaki, G.M. Evaluation antimicrobial and antiadhesive properties of the biosurfactant lunasan produced by Candida sphaerica UCP 0995. Curr. Microbiol. 2011, 62, 1527-1534.

27. Sobrinho, H.B.S.; Rufino, R.D.; Luna, J.M.; Salgueiro, A.A.; Campos-Takaki, G.M.; Leite, L.F.C.; Sarubbo, L.A. Utilization of two agroindustrial by-products for the production of a surfactant by Candida sphaerica UCP0995. Process Biochem. 2008, 43, 912-917.

28. Gusmão, C.A.B.; Rufino, R.D.; Sarubbo, L.A. Laboratory production and characterization of a new biosurfactant from Candida glabrata UCP1002 cultivated in vegetable fat waste applied to the removal of hydrophobic contaminant. World J. Microbiol. Biotechnol. 2010, 26, 1683-1692.

29. Batista, R.M.; Rufino, R.D.; Luna, J.M.; Souza, J.E.G.; Sarubbo, L.A. Effect of medium components on the production of a biosurfactant from Candida tropicalis applied to the removal of hydrophobic contaminants in soil. Water Environ. Res. 2010, 82, 418-425.

30. Santos, C.A.; Bezerra, M.S.; Pereira, H.S.; Santos, E.S.; Macedo, G.R. Production and recovery of rhamnolipids using sugar cane molasses as carbon source. J. Chem. Eng. Chem. Eng. 2010, 4, 27.

31. Al-Bahry, S.N.; Al-Wahaibi, Y.M.; Elshafie, A.E.; Al-Bemani, A.S.; Joshi, S.J.; Al-akhmari, H.S.; Al-Sulaimani, H.S. Biosurfactant production by Bacillus subtilis B20 using date molasses and its possible application in enhanced oil recovery. Int. Biodeterior. Biodegrad. 2013, 81, 141-146.

32. Peypoux, F.; Bonmatin, J.M.; Wallach, J. Recent trends in the biochemistry of Surfactin. Appl. Microbiol. Biotechnol. 1999, 51, 553-563.

33. Lu, J.R.; Zhao, X.B.; Yaseen, M. Biomimetic amphiphiles: Biosurfactants. Curr. Opin. Colloid Interface Sci. 2007, 12, 60-67.

34. Pacwa-Plociniczak, M.; Plaza, G.A.; Piotrowska-Seget, Z.; Cameotra, S.S. Environmental applications of biosurfactants: Recent advances. Int. J. Mol. Sci. 2011, 13, 633-654.

35. Lebrero, R.; Estrada, J.M.; Muñoz, R.; Quijano, G. Toluene mass transfer characterization in a biotrickling filter. Biochem. Eng. J. 2012, 60, 44-49.

36. EPA United States Environmental Protection Agency. Available online: http://water.epa.gov/ lawsregs/lawsguidance/cwa/tmdl/decapb.cfm (accessed on 3 April 2014).

37. EPA United States Environmental Protection Agency. Available online: http://www.epa.gov/ reg3hwmd/risk/human/rb-concentration_table/Generic_Tables/(accessed on 1 May 2014).

38. Lin, C.W.; Chen, L.H.; Yet-Pole, I.; Lai, C.Y. Microbial communities and biodegradation in lab-scale BTEX-contaminated groundwater remediation using an oxygen-releasing reactive barrier. Bioprocess Biosyst. Eng. 2010, 33, 383-391.

39. OESP, O Estado de São Paulo; Diário de São Paulo: São Paulo, Brazil, 2000.

40. Maciel-Souza, M.C.; Macrae, A.; Volpon, A.G.T.; Ferreira, P.S.; Mendonça-Hagler, L.C. Chemical and microbiological characterization of mangrove sediments after a large oil-spill in guanabara bay. Braz. J. Microbiol. 2006, 37, 262-266. 
41. Garza-Gil, M.D.; Prada-Blanco, A.; Vázquez-Rodríguez, M.X. Estimating the short-term economic damages from the Prestige oil spill in the Galician fisheries and tourism. Ecol. Econ. 2006, 58, 842-849.

42. Yeung, C.W.; Law, B.A.; Milligan, T.G.; Lee, K.; Whyte, L.G.; Greer, C.W. Analysis of bacterial diversity and metals in produced water, seawater and sediments from an offshore oil and gas production platform. Mar. Pollut. Bull. 2011, 62, 2095-2105.

43. Asimiea, O.A.; Sam-Wobo, S.O. The impact of hydrocarbon waste from brass oil terminal on the Phytoplancton and Periphyton communities of lower Brass River, Niger Delta, Nigeria. J. Emerg. Trends Eng. Appl. Sci. 2011, 2, 729-733.

44. Costa, A.S.; Romão, L.P.; Araújo, B.R.; Lucas, S.C.; Maciel, S.T.; Wisniewski, A., Jr.; Alexandre, M.R. Environmental strategies to remove volatile aromatic fractions (BTEX) from petroleum industry wastewater using biomass. Bioresour. Technol. 2012, 105, 31-39.

45. Bachmann, R.T.; Johnson, A.C.; Edyean, R.G.J. Biotechnology in the petroleum industry: An overview. Int. Biodeterior. Biodegrad. 2014, 86, 225-237.

46. Olkowska, E.; Polkowska, Z.; Namiésnik, J. Analytical procedures for the determination of surfactants in environmental samples. Talanta 2012, 88, 1-13.

47. Moldes, A.B.; Paradelo, R.; Vecino, X.; Cruz, J.M.; Gudiña, E.; Rodrigues, L.; Teixeira, J.A.; Dominguez, J.M.; Barral, M.T. Partial characterization of biosurfactant from Lactobacillus pentosus and comparison with sodium dodecyl sulphate for the bioremediation of hydrocarbon contaminated soil. BioMed Res. Int. 2013, 2013, doi:10.1155/2013/961842.

48. Moldes, A.B.; Paradelo, R.; Rubinos, D.; Devesa-Rey, R.; Cruz, J.M.; Barral, M.T. Ex situ treatment of hydrocarbon-contaminated soil using biosurfactants from Lactobacillus pentosus. J. Agric. Food Chem. 2011, 59, 9443-9447.

49. Sarubbo, L.A.; Campos-Takaki, G.M. Candida biosurfactant-enhanced removal hydrophobic organic pollutants. In Bioremediation: Biotechnology, Engineering and Environmental Management; Mason, A.C., Ed.; Nova Publishers: New York, NY, USA, 2010; pp. 435-448.

50. EMBRAPA. Plano Nacional de Agroenergia 2006-2011/Ministério da Agricultura, Pecuária e Abastecimento, Secretaria de Produção e Agroenergia, 2nd ed.; Embrapa Informação Tecnológica: Brasília, Brazil, 2006; p. 110.

51. CNI (Confederação Nacional da Indústria). Matriz Energética: Cenários, Oportunidades e Desafios; CNI: Brasília, Brazil, 2007; p. 82.

52. Cerón-Camacho, R.; Martínez-Palou, R.; Chávez-Gómez, B.; Cuéllar, F.; Bernal-Huicochea, C.; Clavel, J.C.; Aburto, J. Synergistic effect of alkyl-O-glucoside and -cellobioside biosurfactants as effective emulsifiers of crude oil in water. A proposal for the transport of heavy crude oil by pipeline. Fuel 2013, 110, 310-317.

53. Assadi, M.; Tabatabaee, M.S. Biosurfactants and their use in upgrading petroleum vacuum distillation residue: A review. Int. J. Environ. Res. 2010, 4, 549-572.

54. Luna, J.M.; Rufino, R.D.; Campos-Takakia, G.M.; Sarubbo, L.A. Properties of the biosurfactant produced by Candida Sphaerica cultivated in low-cost substrates. Chem. Eng. Trans. 2012, 27, $67-72$. 
55. Al-Sulaimani, H.; Joshi, S.; Al-Wahaibi, Y.; Al-Bahry, S.N.; Elshafie, A.; Al-Bemani, A. Microbial biotechnology for enhancing oil recovery: Current developments and future prospects. Biotechnol. Bioinf. Bioeng. J. 2011, 1, 147-158.

56. Sun, S.; Zhang, Z.; Luo, Y.; Zhong, W.; Xiao, M.; Yi, W.; Yub, L.; Fu, P. Exopolysaccharide production by agenetically engineered Enterobacter cloacae strain for microbial enhanced oil recovery. Bioresour. Technol. 2011, 102, 6153-6158.

57. Perfumo, A.; Rancich, I.; Banat, I.M. Possibilities and challenges for biosurfactants use in petroleum industry. Adv. Exp. Med. Biol. 2010, 672, 135-145.

58. Sarafzadeh, P.; Niazi, A.; Oboodi, V.; Ravanbakhsh, M.; Hezave, A.Z.; Shahab Ayatollahi, S.; Raeissi, S. Investigating the efficiency of MEOR processes using Enterobacter cloacae and Bacillus stearothermophilus SUCPM\#14 (biosurfactant-producing strains) in carbonated reservoirs. J. Pet. Sci. Eng. 2014, 113, 46-53.

59. Matsui, T.; Namihira, T.; Mitsuta, T.; Saeki, H. Removal of oil tank bottom sludge by novel biosurfactant, JE1058BS. J. Jpn. Pet. Inst. 2012, 55, 138-141.

60. Diab, A.; El Din, S.G. Application of the biosurfactants produced by Bacillus spp. (SH 20 and SH 26) and Pseudomonas aeruginosa SH 29 isolated from the rhizosphere soil of an Egyptian salt marsh plant for the cleaning of oil - contaminataed vessels and enhancing the biodegradation of oily sludge. Afr. J. Environ. Sci. Technol. 2013, 7, 671-679.

61. Edwards, K.R.; Lepo, J.E.; Lewis, M.A. Toxicity comparison of biosurfactants and synthetic surfactants used in oil spill remediation to two estuarine species. Mar. Pollut. Bull. 2003, 46, 1309-1316.

62. Franzetti, A.; di Gennaro, P.; Bevilacqua, A.; Papacchini, M.; Bestetti, G. Environmental features of two commercial surfactants widely used in soil remediation. Chemosphere 2006, 62, 1474-1480.

63. Franzetti, A; Gandolfi, I.; Raimondi, C.; Bestetti, G.; Banat, I.M.; Smyth, T.J.; Papacchini, M.; Cavallo, M.; Fracchia, L. Environmental fate, toxicity, characteristics and potential applications of novel bioemulsifiers produced by Variovorax paradoxus 7bCT5. Bioresour. Technol. 2012, 108, 245-251.

64. Van Hamme, J.D.; Ward, O.P. Influence of chemical surfactants on the biodegradation of crude oil by a mixed-bacterial culture. Can. J. Microbiol. 1999, 45, 130-137.

65. Singh, A.; van Hamme, J.D.; Ward, O.P. Surfactants in microbiology and biotechnology: Part 2. Application aspects. Biotechnol. Adv. 2007, 25, 99-121.

66. Berninger, J.P.; Williams, E.S.; Brooks, B.W. An initial probabilistic hazard assessment of oil dispersants approved by the United States National Contingency Plan. Environ. Toxicol. Chem. 2011, 30, 1704-1708.

67. Rico-Martínez, R.; Snell, T.W.; Shearer, T.L. Synergistic toxicity of Macondo crude oil and dispersant Corexit 9500A ${ }^{\circledR}$ to the Brachionus plicatilis species complex (Rotifera). Environ. Pollut. 2012, 173, 5-10.

68. Hemmer, M.J.; Barron, M.G.; Greene, R.M. Comparative toxicity of eight oil dispersants, Louisiana sweet crude oil (LSC), and chemically dispersed LSC to two aquatic test species. Environ. Toxicol. Chem. 2011, 30, 2244-2252.

69. U. S. Environmental Protection Agency. Available online: http://www.epa.gov/oppefed1/ ecorisk_ders/toera_analysis eco.htm\#Ecotox (accessed on 12 May 2014). 
70. Anderson, J.A.; Kuhl, A.J.; Anderson, A.N. Toxicity of oil and dispersed oil on juvenile mud crabs, Rhithropanopeus harrisii. Bull. Environ. Contam. Toxicol. 2014, 92, 375-380.

71. Hagner, M.; Penttinen, O.-P.; Pasanen, T.; Tiilikkala, K.; Setälä, H. Acute toxicity of birch tar oil on aquatic organisms. Agric. Food Sci. 2010, 19, 24-32.

72. Lima, T.M.S.; Procópio, L.C.; Brandão, F.D.; Leão, B.A.; Tótola, M.R.; Borges, A.C. Evaluation of bacterial surfactant toxicity towards petroleum degrading microorganisms. Bioresour. Technol. 2011, 102, 2957-2964.

73. Girotti, S.; Ferri, E.N.; Fumo, M.G.; Maiolini, E. Monitoring of environmental pollutants by bioluminescent bacteria. Anal. Chim. Acta 2008, 608, 2-29.

74. Van Beelen, P.; Doelman, P. Significance and application of microbial toxicity tests in assessing ecotoxicological risks of contaminants in soil and sediments. Chemosphere 1997, 34, 455-499.

75. Brinkmann, C.; Eisentraeger, A. Completely automated short-term genotoxicity testing for the assessment of chemicals and characterization of contaminated soils and waste waters. Environ. Sci. Pollut. Res. Int. 2008, 15, 211- 217.

76. Van der Heide, T.; van Nes, E.H.; van Katwijk, M.M.; Scheffer, M.; Jan Hendriks, A.; Smolders, A.J.P. Alternative stable states driven by density-dependent toxicity. Ecosystems 2010, $13,841-850$.

77. Lopes, P.R.M.; Montagnolli, R.N.; Domingues, R.F.; Bidoia, E.D. Toxicity and biodegradation in sandy soil contaminated by lubricant oils. Bull. Environ. Contam. Toxicol. 2010, 84, 454-458.

78. Guven, K.; Togrul, S.; Uyar, F.; Ozant, S.; de Pomerai, D.I. A comparative study of bioassays based on enzyme biosynthesis in Escherichia coli and Bacillus subtilis exposed to heavy metals and organic pesticides. Enzym. Microb. Technol. 2003, 32, 658-664.

79. Reteuna, C.; Vasseur, P.; Cabridenc, R. Performances of three bacterial assays in toxicity assessment. Hydrobiology 1989, 188-189, 149-153.

80. Rosal, R.; Rodea-Palomares, I.; Boltes, K.; Fernández-Piñas, F.; Leganés, F.; Petre, A. Ecotoxicological assessment of surfactants in the aquatic environment: Combined toxicity of docusate sodium with chlorinated pollutants. Chemosphere 2010, 81, 288-293.

81. Sobrinho, H.B.S.; Luna, J.M.; Rufino, R.D.; Porto, A.L.F.; Sarubbo, L.A. Assessment of toxicity of a biosurfactant from Candida sphaerica UCP 0995 cultivated with industrial residues in a bioreactor. Electron. J. Biotechnol. 2013, 16, doi:10.2225/vol16-issue4-fulltext-4.

82. Li, M.H. Effects of nonionic and ionic surfactants on survival, oxidative stress, and cholinesterase activity of planarian. Chemosphere 2008, 70, 1796-803.

83. Goodbody-Gringley, G.; Wetzel, D.L.; Gillon, D.; Pulster, E.; Miller, A.; Ritchie, K.B. Toxicity of deepwater horizon source oil and the chemical dispersant, Corexit ${ }^{\circledR} 9500$, to coral larvae. PLoS One 2013, 2013, doi:10.1371/journal.pone.0045574.

(C) 2014 by the authors; licensee MDPI, Basel, Switzerland. This article is an open access article distributed under the terms and conditions of the Creative Commons Attribution license (http://creativecommons.org/licenses/by/3.0/). 